\title{
LIST OF THE SPHINGIDAE COLLECTED BY THE LATE W. HOFEMANNS AT ALLIANCA, RIO MADEIRA, AMAZONAS.
}

\author{
By the Hon. L. W. ROTHSCHILD and K. JORDAN.
}

W

HEN out collecting one night in November 190 z at Allianca, which lies a short distance beiow S. Antonio, Rio Madeira, the late Wilhelm Hoffmanns passed a locality which is nnder water during the wet season, but at that time of the year was dry, except for some pools of water in the depressions of the ground. His attention was arrested by a number of moths hovering over the pools. The moths proved to be Sphingidae, and W. Hoffmanns at once started to make good use of the opportunity accidentally discovered. He visited the locality almost night after night, often staying nearly till daybreak in the very unhealthy place, and thus obtained a remarkably good collection of about 2500 specimens of Hawkmoths during several weeks of night-collecting in November and December. The following extract (translated) from Hoffmanns's letter refers to this collection :-

"November 25, 1907.-Allianca lies on high ground on the eastern side of the Rio Madeira above the mouth of the Rio Jamary. This 'terra firma' is traversed by a narrow swamp, called 'Japôr.' When out there one night at 6 o'clock I observed Sphingidae over the pools, and since then I have been very bnsy every night catching Hawkmoths. So far I have obtained abont 1500 specimens, but hope to get 2000. All have to be caught with the net, and I have been at it every night as late as 1,2 , or 3 o'clock. When the sun rises all must be put out to dry. It means a very great deal of work. I must remain with the specimens, as there are many enemies here who would play havoc among them, above all the raiu, which may descend any minnte, then pigs, fowls, mules, ants, etc. My weight is now as low as 114 pounds, and I have always a little fever, probably owing to the dampness in the swamp. This being the first time during all my travels that I have met with such an opportunity, I am so enthusiastic that nothing will prevent me from going on with the work, although my legs ache from jumping about so much. Of course, I am obliged to catch every specimen, as it is impossible to recognize anything on the wing and in the darkness. I get consequently of many species long series. The collection, no doubt, will interest you, and I should be very glad if you found good species in it. There are but few butterflies here. No trace of Papilio haleneli.

"November 26. - The rain has interrupted collecting. To-day I obtained for the first time a splendid specimen of one of the larger species.* It is really an Eldorado for Sphingidae. Unfortunately I cannot stay here much longer. The steamer which is to take me down to Marmellos leaves on December 6-8. But collecting is over here anyhow. The water in the depression in the ground begins to rise, and in January canoes pass along there from the Rio Jamary to the Rio Madeira.

"December 2.-The collection of Sphingidae has continued to increase. I have found a second specimen of the brilliant fellow.* Yesterday and to-day were sunny. It is a serious matter that the Sphingidae drink so mach water and dry 
very slowly. On cutting up some a jet of water spurted out. They give me so much to do that they take up all my time.

"December 8.-During the last three days I was occupied with drying the Hawkmoths, and I am still afraid to pack them np. I shall probably be obliged to keep back some which will not get dry."

The specimens arrived in good order. There was no mould among them.

As it is of some interest to know which species frequented the water-pools, we have compared all the specimens and now give a list of the forms the collection contained. The water-drinking habit is, among insects, essentially a feature of the male sex. All the specimens sent by Hoffmanns indeed were males, with the exception of five. However, since the collections made at the pools and other places near Allianca were not strictly kept separate from one another, these females may have been obtained at light or flowers. The presence in the collection of some Ambulicinae and Chaerocampinae may possibly also be explained in the same way.

The Sphingidae which are most abundant in South America are species of the genera Cocytius, Protoparce, Pholus, Xylophanes, and many genera of the subfamily Sesiinae. The majority of the species collected by Hoffmanns are Sesiinae, the other subfamilies being but sparsely represented. Nearly half the number of specimens belong to two species, Pachylia ficus and Pachylia resumens. Next in abundance comes Perigonia lusca f. ilus. Large uumbers were also taken of Pachylia syces, Leucorhampha ornatus, Hemeroplanes nomius, parce, and inuus, Aleuron iplis and neglectum, Nyceryx stuarti, etc., some of which, as a rule, are only obtained singly by collectors. It is not surprising that there are also some novelties in a collection of this size.

\section{Cocytius cluentius Cram. (1775).}

C. c., R. \& J., Revision p. 54. n. 31 (1903).

6 ठे ठे.

\section{Cocytius mortuorum sp. nov.}

of. Closely resembling C. duponchel Poey (1832) in colour and markings; but the black markings on upperside of body and forewing thinner.-Forewing with a conspicuons white line at basal fourth, more or less interrupted and in cell strongly curved outwards; no black longitudinal streaks on disc; the oblique line which extends from apex of wing towards the postdiscal line very thin and mnch interrupted; the semitransparent space present below cell in $C$. duponchel, and covered in that species with regular rows of slightly elevated black scales, is replaced in C.mortuorum by an ill-defined clayish pateh of ordinary scaling. On hindwing the yellow patch of a paler tone, and only slightly siutuate; the transparent area a little larger than in $C$. duponchel.

On underside the yellow colour also of a paler tint, and both wings shaded with yellow along costal margin to apex of cell or beyond.

Legs more extended white than in $C$. duponchel, especially the hind tibia; first foretarsal segment as long as second and third together, comb on inside of this segment absent, except for one or two apical spines.

Genitalia quite different.- $\delta$ : Clasper quite small as compared with the enormous clasper of $C$. duponchel, and much irrorated with creamy white on the outside. Tenth tergite resembling that of $C$. antaeus, long, slender, not incised 
at apex, hardly at all curved in lateral view ; tenth sternite boat-shaped, pointed, the tip slightly pointing upwards. Harpe almost straight, tapering, not curved upwards, pyramid-shaped, with the upper surface concave, the edge armed with many small teeth, which are especially numerous at the apex, one of them standing at the inner edge near the apex being more prominent. Penis-sheath produced into an obtuse lobe ; the apical edge notched on the opposite side.

. Vaginal plate nearest to that of $C$. antaeus; not closely examined.

Length of forewing: $\delta 57-60 \mathrm{~mm}$; \& $72 \mathrm{~mm}$.

6 o $\delta$ from Allianca; 1 i obtained by Ockenden at S. Domingo, Carabaya, South-East Peru, $6000 \mathrm{ft}$., June 1901.

\section{Cocytius duponchel Poey (1832).}

C. d., R. \& J., Revision p. 56 . n. 33 (1903).

$26 \delta \delta$. In one of these specimens the two white discocellular spots are enlarged on each forewing and form a curved, constricted bar.

\section{Protoparce perplexa sp. nov.}

ठ. In colour and markings almost exactly like P. pellenia H.-S. (1854). Head and palpi a little more extended black; underside of abdomen less shaded with fuscous, the base being white._- Forewing broader and along the costal margin darker than in $P$. pellenia, the black sericeous patch situated below $\mathrm{R}^{3}$ longer, the sericeous area consequently more incurved between $\mathrm{R}^{3}$ and costal margin. - The light discal band of the hindwing much shaded with black; the black submarginal band narrower than in $P$. pellenia.

On underside the discal lines of forewing fainter even than in $P$. pellenia. Hindwing darker, only the abdominal area being grejish white; the black-brown discal dentate line single, there being just a vestige of the proximal line found on the disc in $P$. pellenia.

Harpe very much broader than in $P$. pellenia, widest at apex, which is rounded and curved inward. The other parts of the genitalia as in P. pellenia.

$1 \delta$. The conspicnous difference in the harpe induces us to treat the specimen as representing a distinct species.

5. Protoparce rustica rustica Fabr. (1775).

P.r. r., R. \& J., Revision p. 84. n. 53. a (1903).

One pair.

6. Protambulyx eurycles H.-S. (1854).

P. e., R. \& J., Revision p. 175. n. 135 (1903).

$1 \delta$.

7. Protambulyx strigilis L. (1771).

P. \&., R. \& J., Revision p. 179. n. 141 (1903).

5 ठे ठో.

8. Amplypterus palmeri Boisd. (18\%5).

A. p., R. \& J., Revision p. $183, \mathrm{n}, 145$ (1903).

$1 \delta$. 
9. Pseudosphinx tetrio L. (1\% 1$)$.

P. t., R. \& J., Revision p. 353 . n. 283 (1903).

A few $\delta \delta$.

10. Isognathus leachi Swains. (1823).

I. l., R. \& J., Revision p. 353. n. 284 (1903).

23 ठे ठे.

11. Erinnyis alope Drury (17\%3).

E. a., R. \& J., Revision p. 362. n. 292 (1903).

11 ठे ठ.

12. Erinnyis oenotrus Stoll (1780).

E. o., R. \& J., Revision p. 366. n. 296 (1903).

13 ठे ठे.

\section{Pachylia ficus I. (1758).}

P. f., R. \& J., Revision p. 373. n. 302 (1903).

More than 500 specimens, all $\delta \delta$.

14. Pachylia syces syces Hübn. (1822).

P. s. s., R. \& J., Revision p. 374. n. 303. a (1903).

$68 \delta \delta$. The pale costal median patch of the forewing does not extend backwards beyond the lower angle of the cell in any of the specimens.

\section{Pachylia darceta Druce (1881).}

P. d., R. \& J., Revision p. 376 . n. 304 (1903).

5 ठे ठे.

16. Pachylia resumens Walk. (1856).

P.r., R. \& J., Rerision p. 376. n. 305 (1903).

More than 500 specimens.

\section{Oryba kadeni Schauf. (1870).}

O. k., R. \& J., Revision p. 379. n. $306(190$

3 ठेठ

18. Oryba achemenides Cram. (17\%9).

o. a., R. \& J., Revision p. 379. n. 307 (1903).

$1 \delta$.

19. Leucorhampha triptolemus Cram. (17\%9).

L.t., R. \& J., Revision p. 381. n. 308 (1903).

$17 \delta$. One specimen has nearly as much yellowish green on the forewing as the next species.

20. Leucorhampha ornatus Rotbschild (1895).

L. o., R. \& J., Recision p. 382 . n. 310 (1903).

83 ठे ठे. 


\section{Hemeroplanes nomius Walk. (1856).}

H. n., R. \& J., Rerision p. 388, n. 316 (1903).

69 ठे ठे.

\section{Hemeroplanes pan Cram. (17\%9).}

H. p., R. \& J., Revision p. 388, n. 317 (1903).

Now we have seen more material of this rare species, we find that there are two subspecies, which differ as follows :-

\section{(a) H. pan denticulata Schans (1895).}

Calliomma denticulata Schaus, Ent. News vi. p. 141 (1895) (Jalapa).

Forewing more or less strongly dentate, in the $\delta$ the apex sinuate. On the hindwing the black anal spot at least $1 \frac{1}{2} \mathrm{~mm}$. wide. Basal half of forewing beneath tawny.

In the $q$, of which we have now one specimen from Costa Rica (Banana River), the forewing is less dentate than in $\delta$ and broader, with the tip truncate.

This form is found from Mexico to Peru.

$$
\text { (b) H. pan pan Cram. (1\% \%9). }
$$

Sphinx pan Cramer, Pap. Exot, iii. p. 39. t. 216. fig. D (1779) (Surinam).

Apex of forewing truncate, sinus below apex nearly as deep as in denticulata, teeth of margin very small. Hindwing darker along distal margin, being here dusted with black; black anal spot narrower than in the preceding form. On underside the basal area of the forewing with little or no tawny colonr.

Hoffmanns obtained $2 \delta \delta$. We have other specimens, also $\delta \delta$, from the Upper and Lower Amazons (Rio Cachyaco, Pebas, and Pari), and British Guiana (Omai).

\section{Hemeroplanes acuta sp. nov.}

ठ. Body similar to that of $H$. parce, but much deeper in tone, being olivaceous fawn.

Wings, above.—- Forewing narrower than in H.parce, apex sharply pointed, onter margin deeply sinnate below apex ; ground-coloar blackish sepia, the wings appearing much more uniform in colour than in $H$. parce; two triangular costal patches plumbeous, one in middle and the other at the subcostal fork, this second patch without the small dark lunules present in $H$. parce; at the preximal side of the silver spot a dark curved band as in parce but fainter, and farther basad an indistinct pale band edged proximally by a thin pale line ; near base a vestige of another pale band; at hindmargin a plumbeous pateh below the silver spot; outer half of wing with black transverse speckles; no sharply marked oblique apical line as in II. parce, but a plumbeous submarginal cloud before centre of outer margin, outwardly bordered with black. — Hindwing ferrnginous, with a blackish sepia distal border, which is $6 \mathrm{~mm}$. wide at apex and encloses an ill-defined pale bar at anal angle; on dise the vestige of a dark band.

Underside dark fawn, with numerous blackish transverse speckles, both wings bearing a blackish band outside cell ; forewing ferruginous from base to apex of cell, no apical line; lines of dots in outer half of hindwing, like the median line, more prominent than in $H$. parce.

Length of forewing : $32 \mathrm{~mm}$. 
One $\delta$ from Allianca. The style of marking of the forewing recalls dark specimens of $H$. calliomenae. In this species, however, the hindwing is always of a yellow tint, never ferruginous.

We have two more $\delta \delta$ of acutu, one from Chanchamayo, the other without locality (and without head).

24. Hemeroplanes parce Fabr. (17\%5).

H. p., R. \& J., Revision p. 390. n. 320 (1903).

$134 \delta \delta$, which exhibit considerable variability, especially in the distinctness of the markings on the forewing and the amount of black in the marginal area of the hindwing.

25. Hemeroplanes inuus R. \& J. (1903).

H. i., R. \& J., Revision p. 391. n. 321 (1903).

69 ठे ठे.

26. Aleuron carinata Walk. (1856).

A. c., R. \& J., Revision p. 395. n. 324 (1903).

8 ठे ठे.

27. Aleuron chloroptera Perty (1834).

A. c., R. \& J., Revision p. 396 . n. 327 (1903).

38 ठे ठे.

28. Aleuron iphis Walk. (1856).

A. i., R. \& J., Revision p. 398. n. 329 (1903).

58 ठे ठे.

29. Aleuron neglectum R. \& J. (1903).

A. n., R. \& J., Revision p. 398 . n. 330 (1903).

$72 \delta \delta$. A darker insect than the preceding one ; the white line on the forewing sometimes barely vestigial.

30. Enyo japix ljapix Cram. (1776).

E. j.j., R. \& J., Revision p. 400. n. 331. a (1903).

13 ठे के.

31. Epistor lugubris lugubris L. (1771).

E. l. l., R. \& J., Revision p. 404. n. 333. a (1903).

$4 \delta \delta$.

32. Epistor ocypete L. (1758).

E. o., R. \& J., Revision p. 405. n. 334 (1903).

$71 \delta \delta$ and 1 \&.

33. Epistor gorgon Cram. (17\%7).

E. g., R. \& J., Revision p. 405. n. 335 (1903).

$4 \delta 8$.

34. Epistor cavifer R. \& J. (1903).

E. c., R. \& J., Revision p. 407, n, 337 (1903).

$2 \delta \delta$. 
35. Pachygonia caliginosa Feld. (1874).

P.c., R. \& J., Revision p. 410. n. 339 (1903).

800 ठे.

36. Nyceryx coffeae Walk. (1856).

N. c., R. \& J., Revision p. 417. n. 349 (1903).

38 oे ठे.

37. Nyceryx magna Feld. (18\%4).

N. m., R. \& J., Revision p. 418, n. 350 (1903).

$4 \delta \delta$. This species is very rare in collections.

38. Nyceryx riscus Schans (1890).

N. r, R. \& J., Revision p. 422 , n. 357 (1903).

$18 \delta \delta$, of more than average size.

39. Nyceryx stuarti Rothsch. (1894).

N. s., R. \& J., Revision p. 422. n. 358 (1903).

45 o $\delta$. This species and riscus resemble each other closely; they are distinguishable, apart from the genitalia, by the dark marginal band of the forewing being wider at hind angle in stuarti than in riscus. On the underside, the posterior half of the submarginal line on the forewing and the distal border of the hindwing are less prominent in stuarti than in riscus; also the S-shaped lines are fainter in stuarti, and the cell of the forewing is not or but very little shaded with fuscons.

40a. Perigonia lusca f. ilus Boisd. (1870).

P. l. f. i., R. \& J., Revision p. 428. n. 363. $c^{1}$ (1903).

340 ठ $\delta$. Variable in size. The yellow band of the hindwing broader in some specimens than in others.

40b. Perigonia lusca f. interrupta Walk. (1864).

P.l. f. i., R. \& J., Revision p. 428, n. 363. d (1903).

$4 \delta$ ठे.

[40c. Perigonia lusca f. restituta Walk. (1864).

P. l. f. r., R. \& J., Revision p. 428. n. $363 . e^{1}(1903)$.

$4 \delta$ ठे.

41. Eupyrrhoglossum sagra Poey (1832).

E. s., R. \& J., Revision p. 430 . n. 367 (1903).

43 ठे ठे.

42. Eupyrrhoglossum venustum sp. nov.

o. Head and thorax above black-brown (dark mummy-brown), with two broad plumbeous stripes; head with slight mesial crest. End-segment of antenna cylindrical. Abdomen black-brown at base, tergites 4 and 5 dark chestnut, shaded with plumbeous; tergites 6 and 7 black with chestnut fringes, a large central spot and a smaller lateral spot on each.plumbeous; tripartite tail large, black-brown with yellow spot at apex of lateral lobes and two subbasal dorsal plumbeous spots, 
tip of mesial lobe chestnut. On underside the palpus creamy white, breast and first three abdominal sternites maize-yellow, paler than in E.corvus, this colour extending on to the lower edge of the tergites, rest of abdomen pale chestnut, the sternites of segments 5 and 6 bearing a yellowish spot towards each side.

Wings, above.—-Forewing narrower and longer than in E. sagra, black-brown, plumbeous between the lines; seven black-brown transverse lines between base and vein $\mathrm{M}^{1}$; lines 2 and 3 and again 6 and 7 more or less fused, this last donble line nearly straight; a stigma similar to an inverted comma, with a dot in front of it; on disc 5 parallel, somewhat dentate, S-shaped lines, partly effaced between $\mathrm{R}^{3}$ and $\mathrm{SM}^{2}$, where the wing is paler brown and is flushed with plumbeous; the fifth line broad, being narrowed before $\mathrm{R}^{3}$; a submarginal line, which runs from the apical angle of the wing to the hinder angle, joins the fifth discal one before $\mathrm{R}^{3}$, and is coincident with it from there to hind angle ; outer margin a little more convex in centre than in sagra._-Hindwing brownish black; a greenish yellow central band broader than in sagra, much paler than in corvus; a slight admarginal line and a similar submarginal one plumbeons, a third line indicated behind; fringe creamy buff, yellow at anal angle.

Underside pale hazel. Basal half of forewing blackish, shaded with yellowish; on dise two brown dentate lines in S-shape and a third faint one between them; a faint undulate line from apex, joining onter discal line at $\mathrm{R}^{2}$. — Hindwing from base to anal angle maize-yellow, this colour gradually fading away towards dise; three brown lines in onter half, the first in middle, nearly straight, the second and third curved costad and slightly dentate.

Length of forewing: $31 \mathrm{~mm}$.

$1 \delta$ from Allianca. At once distinguished from E. corvus by the pale tint of the band of the hindwing and the breast, and the numerons brown-black lines on the upperside of the forewing.

\section{Sesia ceculus Cram. (1\%\%).}

S. c., R. \& J., Revision p. 423. n. 369 (1903).

Five large and two small $\delta \delta$.

44. Sesia fadus Cram. (17\%5).

S.f., R. \& J., Revision p. 437. n. 373 (1903).

Three worn of $\delta$.

45. Pholus anchemolus Cram. (17\%9).

P. a., R. \& J., Revision p. 478, n. 404 (1903).

One pair.

46. Pholus satellitia licaon Cram. (17\%5).

P. s.l., R. \& J., Revision p. 482, n. 406.c (1903).

$4 \delta \delta^{\circ}$.

47. Xylophanes schausi serenus subsp. nov.

Xylophanes schausi, R. \& J., Revision P. 686. n. 632 (1903) (partim ; Venezuela).

The olivaceons submarginal patch between the radials on the npperside of the forewing very slightly indicated, while it is prominent in the southern form, X. s. schausi from Brazil (Rio, Espiritu Santo). 
$1 \delta$ from Allianca (type) and 2 $q$ from Aroa, Veneznela.

The specimen figured in the Revision (pl. ix. fig. 13) is a $\delta$, not a. $f$ as stated l.c.; we had at that time $4 \delta \delta$ from Brazil and 2 of from Veneznela. The sexen are practically alike in colour and markings.

48. Xylophanes cosmius obscurus subsp. nov.

ๆ. Resembles X. cosmius R. \& J., Nov. Zool. p. 183 . n. 12 (1906), from Sonth-East Peru.

Upperside. The antemedian donble line of the forewing straight across cell, elbowed at M, not at SC as in $X$. cosmius and epaphus; the black median patch larger than in the two species mentioned; the discal line distinctly though feebly curved basad below centre of wing, reaching hindmargin in middle; area between this line and distal margin as in cosmius and epaphus, but the blackish portion of a deeper tone ; fringe withont distinct pale spot, except for a minute one at apex.-Hindwing as in cosmius, but the band less green and the margin entirely black; fringe white, with minute black dots at the veins.

Underside more densely irrorated than in the allied forms, and the marginal band broader and purplish black. On the forewing the two black costal spots less prominent, and the basal half of the wing more extended black.

1 f. This specimen was among Hoffmanns's butterflies, and we may therefore assume that it was not canght at the pools drinking. As we do not know the $q$ of cosmius and have seen only two $q f$ of epaphus, we are not yet certain if obscurus is a distinct species or a geographical form of cosmius. In order to emphasize its close affinity with cosmius, we treat it as a subspecies.

49. Xylophanes chiron nechus Cram. (1\%\%).

X. ch. n., R. \& J., Revision p. 698, n. 651. a (1903).

5 ठठ ठ, 1 ․ 


\section{$2 \mathrm{BHL}$ Biodiversity Heritage Library}

1910. "List of the Sphingidae collected by the late W. Hoffmanns at Allianca, Rio Madeira, Amazonas." Novitates zoologicae : a journal of zoology in connection with the Tring Museum 17, 447-455.

https://doi.org/10.5962/bhl.part.13692.

View This Item Online: $\underline{\text { https://www.biodiversitylibrary.org/item/22248 }}$

DOI: https://doi.org/10.5962/bhl.part.13692

Permalink: https://www.biodiversitylibrary.org/partpdf/13692

\section{Holding Institution}

Natural History Museum Library, London

\section{Sponsored by}

Natural History Museum Library, London

\section{Copyright \& Reuse}

Copyright Status: Public domain. The BHL considers that this work is no longer under copyright protection.

This document was created from content at the Biodiversity Heritage Library, the world's largest open access digital library for biodiversity literature and archives. Visit BHL at https://www.biodiversitylibrary.org. 